\title{
Isolation and Utilization of Protease Lactic Acid Bacteria as Meat Tenderizer
}

\author{
Prima Retno Wikandari \\ Department of Chemistry \\ Universitas Negeri Surabaya \\ Surabaya, Indonesia \\ primaretno@unesa.ac.id
}

\author{
Diah Puri P. Panggayuh \\ Department of Chemistry \\ Universitas Negeri Surabaya \\ Surabaya, Indonesia
}

\author{
I Gusti Ngurah Agung Oka Dhana \\ Department of Chemistry \\ Universitas Negeri Surabaya \\ Surabaya, Indonesia
}

\begin{abstract}
The objective of this research was to observe the potency of protease of Lactobacillus LBP 1 as meat tenderizer. The study included the proteolytic enzyme activity and the effect of the enzyme concentration to meat tenderizing. The isolation of protease used ammonium sulphate of $15,30,40$, and $60 \%$, to be determined their specific activities. The enzyme activity was calculated as the number of protease which catalysed the releasing $1 \mu \mathrm{mol}$ of tyrosin per minute and was measured by spectrophotometer at wave length of $274 \mathrm{~nm}$. Fraction which has the highest activity then was chosen for dialysis process and the specific activity was determined. Meat tenderizing was done by immersed the meat into the enzyme extract in concentration of $0.25,0.50,0.75$ and $1.00 \%$ respectively for $30 \mathrm{~min}$. The meat tenderize was measured by penetrometer. Fraction of $45 \%$ ammonium sulphate showed the highest activity and has specific activity of $0.794 \mathrm{U} / \mathrm{mg}$. Partial purificationby ammonium sulfate of this fraction by dialysis process showed a specific activity of $1.202 \mathrm{Unit} / \mathrm{mg}$. Tenderizing of meat score correlated with the enzyme concentration and give the tenderize score of $5.3 \mathrm{~mm} / \mathrm{g} / 10 \mathrm{~s}, 5.8$ $\mathrm{mm} / \mathrm{g} / 10 \mathrm{~s}$, $6.9 \mathrm{~mm} / \mathrm{g} / 10 \mathrm{~s}$ for immersing of enzyme concentration of $0.25,0.50,0.75$ and $1.00 \%$ respectively for 30 min.
\end{abstract}

Keywords-Lactic acid bacteria, proteolitic enzyme, specific activity, meat tenderizer

\section{INTRODUCTION}

Meat tenderizing is one of the problems for meat consumption. Protease from plant like papaya and pineapple Exploration of the protease sources showed that protease derived bacterially could be used as meat tenderizing. Production of protease derived from microorganism has some advantages, i.e. produced in a large amount, has an equal quality, cheaper cost, produced in a short time and the growth can be managed easily[1]. Protease derived bacterially more were produced more than plan or animal derived protease [2].

Protease enzyme will digest meat protein like collagen, and elastin to be shorter fibers which lessen the toughness of meat. Lactic acid bacteria mostly was found in fermented food and showed characteristic as non pathogenic bacteria. Some research showed that some species of this bacteria potentially as proteolytic bacteria [3][4] and many of these enzymes were known have activities to degrade the myofibrilar and sarcoplasma proteins in meat [5][6][7] Bekasam is one of fish fermented foods which are produced traditionally in Indonesia. We has isolated some of proteolytic lactic acid bacteria from it product which included some strains of Pediococcos and Lactobacillus, which have been identified qualitatively using MRS-Casein Agar based on the clear zone area. The highest proteolitic was given by a bacteria namely of LBP 1[8]. In this research the specific activity of the proteolytic derived enzyme of LBP 1 was evaluated and then developed as an alternative of meat tenderizer. The effect of enzyme concentration to meat tenderizing were observed at a definite time.

\section{METHODS}

\section{A. Culturing of $L B P I$}

The isolate bacteria stock was subcultured twice. About $1 \%$ of isolate was inoculated to MRS broth (Oxoid) and incubated at $37^{\circ} \mathrm{C}$ for $20 \mathrm{~h}$. The suspension then was centrifuged (Eppendorf) for 15 minutes at $3500 \mathrm{rpm}$, supernatant were discarded and the pellet were suspended in by50 $\mathrm{mL}$ of sterilized $\mathrm{NaCl} 0.85 \%$. This mixture then was used as a culturing starter of LAB bacteria as enzyme producer.

\section{B. Production of Protease Derived Bacterially}

$20 \mathrm{~mL}$ of inoculum were inoculated in $180 \mathrm{~mL}$ MRS Broth containing of $5 \%$ casein $(\mathrm{b} / \mathrm{v})$, then was shake at $120 \mathrm{rpm}$ at $37^{\circ} \mathrm{C}$ for $16 \mathrm{~h}$. After that the mixture then was centrifuged at $5000 \mathrm{rpm}$ at temperature $4^{\circ} \mathrm{C}$ for $15 \mathrm{~min}$. The supernatan contained protease enzyme were collected and isolated using ammonium sulfate

\section{Isolation of Protease}

About of $50 \mathrm{~mL}$ of supernatant was added by $15 \%, 30 \%$, $45 \%$ and $60 \%(\mathrm{~b} / \mathrm{v})$ of amonium sulfate respectively. The mixture then were centrifuged, the residue were collected and about $15 \mathrm{~mL}$ of phosphate buffer $\mathrm{pH} 7$ then was added and keep at temperature of $4^{\circ} \mathrm{C}$. Each of some fractions then were measured their activity and the protein content

\section{Purification of Protease}

About $7 \mathrm{~mL}$ of the highest activity fraction from isolation process was put into a dialysis pocket and was dialyzed in $70 \mathrm{~mL}$ phosphate buffer $\mathrm{pH} 7$ at $4^{\circ} \mathrm{C}$. Dialysis process was done until the solvent has no $\mathrm{BaSO}_{4}$ containing that were tested using $1 \% \mathrm{BaCl}_{2}$ 


\section{E. Determination of enzyme activity}

About $2 \mathrm{~mL}$ of sample was added to $2 \mathrm{~mL} 0.05 \mathrm{M}$ of phosphate buffer $\mathrm{pH}$ 7. After $5 \mathrm{~min}$, the mixture then was added by $2 \mathrm{~mL}$ of $2 \%$ casein (in $0.05 \mathrm{M}$ phosphate buffer $\mathrm{pH} 7$ ) casein as a substrate and incubated for $10 \mathrm{~min}$ at $37^{\circ} \mathrm{C}$ Put $4 \mathrm{~mL}$ of $0.4 \mathrm{M}$ TCA to each sample and the mixture were incubated again for $30 \mathrm{~min}$. The mixture were centrifuge at $500 \mathrm{rpm}$ at $4^{\circ} \mathrm{C}$ for $10 \mathrm{~min}$. The supernatan then were collected and measured their absorbance at wave length of $274 \mathrm{~nm}$. Protease activity was expressed in unit (U) which is defined as the number of protease which catalysis the lost of $1 \mu \mathrm{mol}$ tirosin per min. Enzyme activity was calculated by equation below.

$$
\begin{array}{ll}
\text { Activity } & =\frac{[\text { Tyrosin }]}{\text { Mm tyrosin }} \times \frac{\mathrm{V}}{\mathrm{p} \mathrm{x} \mathrm{q}} \times \mathrm{fd} \\
\mathrm{V} & : \text { volume of sample }(\mathrm{mL}) \\
\mathrm{p} & \text { : volume of enzyme }(\mathrm{mL}) \\
\mathrm{q} & : \text { incubation time }(\text { minute) } \\
\mathrm{fd} & \text { : dilution factor } \\
\mathrm{Mm} \text { tirosin: } & 181.19 \text { (gram/mol) }
\end{array}
$$

\section{F. Determination of Protein}

About of $0.5 \mathrm{~mL}$ sample was added with $5 \mathrm{~mL}$ Biuret reagent. Homogenized the mixture and stand at room temperature for $10 \mathrm{~min}$. About of $0.5 \mathrm{~mL}$ Follin Ciocalteu reagent then was added to the mixture, stand at room temperature for about $30 \mathrm{~min}$. The solution was measured its absorbance by spectrophotometer at wave length of $708 \mathrm{~nm}$. Standard curve was made using BSA as a standard.

\section{G. Production of protease derived LBP-1 used for meat tenderizer}

About $10 \mathrm{~mL}$ of stock culture of LBP-1 were inoculated in $90 \mathrm{~mL}$ of growth media $(80 \mathrm{~mL}$ MRS broth $+10 \mathrm{~mL} 5 \%$ casein) then were incubated for $16 \mathrm{j}$ at $37^{\circ} \mathrm{C}$. After that, about $100 \mathrm{~mL}$ of culture mixture were inoculated into 900 $\mathrm{mL}$ of the growth medium $(800 \mathrm{~mL}$ MRS Broth $+100 \mathrm{~mL}$ of $5 \%$ casein), incubated for $16 \mathrm{~h}$ at $37^{\circ} \mathrm{C}$. The mixture then was centrifuged at $5000 \mathrm{rpm}$ for about $10 \mathrm{~min}$ at $4^{\circ} \mathrm{C}$. The supernatant were collected and were precipated using ammonium sulphate $45 \%$. The residue was separated using centrifugation at $5000 \mathrm{rpm}$ at $4^{\circ} \mathrm{C}$, then was filtered using Whatman No. 1, washed using acetone and dried at room temperature. The dried crude enzyme then was dissolved into phosphate buffer $\mathrm{pH} 7$.

\section{H. Measurement the effect of enzyme concentration to meat tenderizing}

Meat was cut into $2 \times 2 \times 2 \mathrm{~cm}$, then were immersed in enzyme solution for concentration of $0.25,0.50,0.75$ and $1.00 \%(\mathrm{~b} / \mathrm{v})$ respectively for about 30 minutes. Measurement of meat tenderizing was done using penetrometer.

\section{RESULTS AND DISCUSSION}

\section{A. Enzyme activities of fraction precipitation with} ammonium sulphate and dialysis

Protease enzyme which was produced by inoculation of LBP 1 in MRS medium containing 5\% casein was precipited using 15\%, 30\%, 45\% and 60\% ammonium

TABLE I. ENZYME ACTIVITIES OF SOME FRACTION OF PRECIPITATION WITH AMMONIUM SULPHATE

\begin{tabular}{lccc}
\hline $\begin{array}{l}\text { Fraction precipated of } \\
\text { ammonium sulfate }\end{array}$ & $\begin{array}{c}\text { Enzyme activity } \\
(\mathrm{U} / \mathrm{mL})\end{array}$ & $\begin{array}{c}\text { Protein } \\
(\mathrm{mg} / \mathrm{mL})\end{array}$ & $\begin{array}{c}\text { Specific activity } \\
(\mathrm{U} / \mathrm{mg})\end{array}$ \\
\hline $15 \%$ & 0.230 & 0.587 & 0.392 \\
$30 \%$ & 0.339 & 0.813 & 0.417 \\
$45 \%$ & 0.697 & 0.880 & 0.794 \\
$60 \%$ & 0.319 & 1.585 & 0.201 \\
\hline
\end{tabular}

sulfate respectively and were evaluated their activity as is shown at Table 1.

Precipitation at $45 \%$ ammonium sulfate gives the highest specific enzyme $(0.794 \mathrm{U} / \mathrm{mg})$, it means that $45 \%$ ammonium sulfate gives the best condition of salting out for protease enzyme derived from LBP-1. In salting out process, the solubility of protein decreases caused by a competition of salt ions and protein in binding the water molecule. Ammonium sulfate has ability to pull the water molecule on the surface of enzyme, so that enzyme molecule will form an aggregate. Precipatation of protease enzyme isolated from Lactobacillus acidophilus was also found that precipitation with $45 \%$ ammonium sulfate gave the highest specific activity, but LBP-1 protease gave a lower activity (0.794 U/mg) then L.acidophilus protease (1.24 U/mg) [9]. LBP-1 protease enzyme has a higher activity than Bacillus substilis 1012M15 (0.475 U/mg) [10].

The best fraction of enzyme which gave the highest specific activity was purified using dialysis process and gave an increasing of specific activity as is shown at Tabel II.

TABLE II. ENZYME ACTIVITIES OF PROTEASE DERIVED LBP-1

\begin{tabular}{lccc}
\hline Enzyme & $\begin{array}{c}\text { Enzyme activity } \\
(\mathrm{U} / \mathrm{mL})\end{array}$ & $\begin{array}{l}\text { Protein } \\
(\mathrm{mg} / \mathrm{mL})\end{array}$ & $\begin{array}{c}\text { Specific activity } \\
(\mathrm{U} / \mathrm{mg})\end{array}$ \\
\hline Crude extract & 0.316 & 3.021 & 0.045 \\
Ammonium sulfate $45 \%$ & 0.697 & 0.080 & 0.794 \\
Dialysis & 0.877 & 0.729 & 1.202 \\
\hline
\end{tabular}




\section{B. The effect of enzyme consentration to meat tenderizing}

The toughness of meat closely related to sarcomere protein. Degradation of meat sarcomere including a breakdown of myofibril and connective tissue i.e. collagen and elastin, and therefore produced a more tender meat [11]. Heat treatment and degradation of these proteins by protease enzyme will produce a tenderize meat. In this research, LBP-1 protease enzyme was used as meat tenderize and the effect of it protease consentration were evaluated (Tabel III).

The result of this treatment showed that increasing of enzyme concentration was followed by increasing of meat tenderizing. At enzyme concentration of $0.25 \%$, $0.50 \%, 0.75 \%$, and $1.00 \%$, the tenderize score are 5.3 $\mathrm{mm} / \mathrm{g} / 10 \mathrm{~s}, 5.8 \mathrm{~mm} / \mathrm{g} / 10 \mathrm{~s}, 6.9 \mathrm{~mm} / \mathrm{g} / 10 \mathrm{~s}$ and $8.0 \mathrm{~mm} / \mathrm{g} / 10 \mathrm{~s}$ respectively. Based on standard score of meat tenderizing, the best treatment was immersing of meat in $0.25 \%-0.50 \%$ protease enzyme for $30 \mathrm{~min}$, which represented from tender $(6 \mathrm{~mm} / \mathrm{g} / 10 \mathrm{~s})$ to very tender $(7 \mathrm{~mm} / \mathrm{g} / 10 \mathrm{~s})$

TABLE III. THE EFFECT OF ENZYME CONCENTRATION TO MEAT TENDERIZING

\begin{tabular}{cc}
\hline Enzyme cons \% (b/v) & Meat tenderizing $(\mathrm{mm} / \mathrm{g} / 10 \mathrm{~s})$ \\
\hline 0.00 & 4.6 \\
0.25 & 5.3 \\
0.50 & 5.8 \\
0.75 & 6.9 \\
1.00 & 8.0 \\
\hline
\end{tabular}

\section{CONCLUSION}

Protease derived LPB-1 was potentially to be develop industrially especially for meat tenderize because of its activity and the ability to tender meat.

\section{ACKNOWLEDGMENT}

The authors are greatly thankful to laboratory assistance team whose had assisted this research, and the Head Department of Chemistry Faculty of Mathematics and Natural Science, Universitas Negeri Surabaya for providing of support and facilities.

\section{REFERENCES}

[1] Wijayanti, Novita. 2006. Karakterisasi Parsial Ekstrak Kasar Enzim Protease dari Bacillus amyloliquefaciens NRRL B-14396. Jurnal Teknologi Pertanian. 7 (2): 96-105.

[2] Fatoni, Amin. 2008. Isolasi dan Karakteisasi Protease Ekstraseluler dari Bakteri dalam Limbah Cair Tahu. Jurnal Natur Indonesia. 10 (2): 83-88

[3] Mauriello, G., Casaburi, A., Villani, F. 2002. Proteolytic Activity of Staphylococcus xylosus Strain on Pork Myofibrillar and Sarcoplasmic Protein and Use of The Selected Strain in The Production of "Naple Type" Salami. Journal Applied Microbiology. 93 (3) : 482 - 490

[4] Akta, N., Aksu, M.I., Kaya, M. 2004. Changes in Myofibrillar Protein During Processing of Pastrima (Turkey dry meat product) Produced With Commercial Starter. Food Chemistry. 90 (4) : 649 - 654. Basso, A.L., Picariello, G., Coppola, R., Tremonte, P., Musso, S.S., Luccia, A.D. 2004. Proteolytic Activity of Lactobacillus sakei, Lactobacillus farciminis and Lactobacillus plantarum on Sarcoplasmic Protein of Pork Lean. Journal of Food Biochemistry. 28: 195-212.

[5] Sriphochanart, W. dan Wanwisa, S. 2010. Characterization of Proteolytic Effect of Lactic Acid Bacteria Starter Cultures on Thai Fermented Sausages. Food Biotechnology. 24 (4) : 293 - 311.

[6] Rai, K.P., Shrestha, A.K., Xia, W. 2008. Proteolytic Effect of Starter Culture on Dry Fermented Chinese-Style Sausage. Journal of Food Science and Technology Nepal. $4: 64-69$.

[7] Xu, Y., Wenshui, X., Fang, Y., Xiahua, N. 2010. Physical and chemical changes of silver carp sausages during fermentation with Pediococcus pentosaceus.. Food Chemistry. 122 (3) : 633-637.

[8] Wikandari. P.R., Suparmo, Yustinus Marson dan Endang Sutriswati Rahayu, 2012. Karakteristik Bakteri Asam Laktat Proteolitik pada Bekasam. Jurnal Natur Indonesia. 14 (2) : 120-125.

[9] Putranto. 2007. Aktivitas Proteolitik Lactobacillus acidophilus dalam Fermentasi Susu Sapi. Jurnal Ilmu Ternak. 7 (1): 67-72.

[10] Susanti, Elfi. 2003.Isolasi dan Karakterisasi Protesae dari Bacillus subtilis 1012M15. Jurnal Biodiversitas. 4 (1): 12-17.

[11] Somanjaya. Rachmat, 2003. Pengaruh Enzim Papain terhadap Keempukan Daging. Jurnal Ilmu Pertanian dan Perternakan. Vol. 1 (2) : hal. 3-5. 